Article

\title{
Citizen Art and Human Rights: Collective Theatre Creation as a Way of Combatting Exclusion
}

\author{
Manuel Muñoz-Bellerín * and Nuria Cordero-Ramos \\ Department of Social Work and Social Services, Pablo de Olavide University, Spain; E-Mails: mfmunbel@upo.es (M.M.-B), \\ ncorram@upo.es (N.C.-R) \\ * Corresponding author
}

Submitted: 15 April 2021 | Accepted: 22 July 2021 | Published: 30 November 2021

\begin{abstract}
In this article, through the lens of critical theory and collective theatre creation, we will look at how a group of homeless individuals in the city of Seville (Spain) has been able to assert their human rights using art. Through the words of the actors themselves, we will reveal the obstacles they face in accessing the city's public sphere, and their deconstruction. By creating and producing plays, as well as interacting with the audience, the participants became not just actors, but citizens with rights. Collective theatre creation, as adapted by the authors within the context of their research in the field of social work, provides insights into how art has the power to become a strategy for helping those living on the fringes of mainstream society reclaim their place in it politically and culturally. This research has been made possible thanks to the commitment of the members of Teatro de la Inclusión, a theatre group and socio-artistic project that ran for twelve years and allowed homeless individuals, tired of being passive subjects, dependent on external assistance and subject to endless bureaucracy, to become amateur actors. In doing so, they created for themselves dignified forums in which to express themselves within their city and put their communicative and artistic skills into practice.
\end{abstract}

\section{Keywords}

collective theatre creation; homelessness; homeless persons; human rights; inclusion theatre

\section{Issue}

This article is part of the issue "Art and Design for Social Inclusion in the Public Sphere" edited by Karin Hannes (KU Leuven, Belgium).

(C) 2021 by the authors; licensee Cogitatio (Lisbon, Portugal). This article is licensed under a Creative Commons Attribution 4.0 International License (CC BY).

\section{Introduction}

This article looks at the appropriation of public spaces in the city of Seville by a group of homeless individuals, a process made possible by the use of theatrical productions created using the collective theatre creation method. These plays gave participants the opportunity to move from spaces assigned to them by society (homeless shelters, soup kitchens, day centres, etc.) to public spaces they tend to be excluded from, such as theatres, universities, and cultural centres.

We will begin by outlining the concepts on which this article is based, namely critical theory of human rights and collective theatre creation. We will then present Teatro de la Inclusión, an amateur theatre group which ran from 2007 to 2019 in Seville (Spain). The group allowed its homeless members to use art as a way of expressing their feelings of helplessness and exclusion, providing them with a tool with which to assert their rights, and thus grow and empower themselves. This was a forum where their stories took centre stage. Through the development of their artistic capacities, the members of the group were able to form a collective voice in order to assert their right and dignity.

Lastly, we will provide an overview of the plays written and performed over the twelve years during which the project ran. These not only allowed actors to assert their rights, but were also an opportunity for the audience to find out about their plight. This use of collective theatre creation clearly showed just how effective it can 
be as a tool for fostering democratisation and bringing people together in the name of social transformation.

\section{Human Rights as Cultural Products: The Theatre as a Space for Recognition}

Throughout this article, when we use the term "human rights," we do so within the critical perspective formulated by de Sousa Santos and Sena Martins (2021), who consider them to be spaces where struggles for human dignity take place. Herrera Flores (2008, p. 13) echoes this when he talks about a "new perspective of rights as institutional and social processes which enable the emergence and consolidation of spaces for struggles of human dignity."

The descriptions of human rights given by various authors (Gallardo, 2006; Ignatieff, 2017; Sikkink, 2017) may be seen as the restoration of identities which have been damaged by hegemonic practices. Based on this approach, human rights may be associated with the selfdetermination of individuals, communities and groups within society, which for Ignatieff $(2017$, p. 11) is "the right to determine their own destiny as political agents." Here, culture as a space for methodological action plays a central role. For Gramsci, cultural action is the "coming to terms with one's own personality; it is the attainment of a higher awareness with the aid of which one succeeds in understanding one's own historical value, one's own function in life, one's own rights and obligations" (as cited in Crehan, 2002, p. 74). Theatre is a meaningful cultural practice within processes of resistance, as it brings out the capacities and potential of each individual (Muñoz-Bellerín \& Cordero-Ramos, 2020). The concept of the imaginary, as put forth by authors such as Castoriadis (1987), serves to demonstrate the potential of the theatre as a tool through which to give oppressed individuals a chance to express their worlds and assert their rights. In strategies such as the one presented in this article, the radical imaginary is harnessed in spaces for dialogue and participation, where oppressed individuals, in our case homeless persons, are able to discuss the causes and consequences of their spoiled identities and thus the stigma they suffer on a daily basis (Goffman, 1990).

Indeed, theatre has long since been regarded as a strategy of resistance (Barba \& Savarese, 2019). Other theoretical and practical strategies have also been created by theatre practitioners, such as Brecht, who argued for "scientific drama," a tool through which to analyse and identify the structures of domination present in the capitalist system (Brecht, 2019, p. 172). For Brecht, it was important that theatre brought to light social conditions based on subordination, a reflection of his belief that "reality must be transformed through art for it to be acknowledged and treated like something that can be changed" (Brecht, 2004, p. 31).

These ideas are both based on the use of theatre as a tool for critically questioning social conditions which result in domination and oppression. The creative dimension of theatre allows for analysis, debate and, above all, new ways of interacting with one another and coexisting, based on equality, diversity and fairness. By viewing theatre as a cultural product which allows us to do and undo worlds (Herrera Flores, 2005), it becomes a participatory tool of action and reaction for transforming realities involving exclusion.

We chose to use collective theatre creation for our work with Teatro de la Inclusión for the latter's great emancipatory potential: The group enabled its participants to assert their human rights in public spaces as they told their stories. The first documented use of collective theatre creation was developed by Joan Littlewood in England in the 1940s and 50s (Holdsworth, 2017). It later appeared in the rest of Europe and Latin America in the 1960s and 70s, where great advances were made in terms of methodology and artistic output. In Latin America, it was adopted by independent theatre groups as a means of affirming their identify in the face of colonial dominance based on hegemonic cultural practices. In fact, the work on which this article is based on has been influenced to a large degree by a number of Colombian playwrights and stage directors responsible for standardising this methodology, something that has made collective, open, and spontaneous, yet structured, theatrical productions possible. In the words of Cardona Garzón (2009, p. 108), this is a scientific methodology which is "preceded and accompanied by research at various levels, including historical, sociological and political, as well as scientific research surrounding the artistic work itself." Another noteworthy proponent of collective theatre creation, Santiago García Pinzón, who was the director of the theatre group La Candelaria for half a century, prefers to talk about a flexible and experimental, yet standardised, work process (García Pinzón, 2002).

The theatrical productions created by Teatro de la Inclusión were the result of a form of social and educational intervention which adhered to criteria taken from the humanistic social sciences and established theatre practices. The main aim was to give those who had been silenced a forum where they were able to take centre stage and reclaim their voice by asserting themselves in the city's public sphere, from which they are commonly excluded. Our work with this amateur theatre group led to us undertake participatory action research, as well as become involved in artivism with its members (Duncombe, 2016), whose circumstances varied significantly, with some living in homeless shelters, others on the street, and others in sheltered housing. By basing the productions on the real-life experiences and challenges of the participants, the probability of them getting fully involved in the process was maximised. The aim was not to create plays which were disconnected from their reality and needs but instead to construct a narrative discourse through theatre where they were the facilitators, authors and actors. Nevertheless, given the critical process involved in participatory action research, we feel it 
necessary to outline some issues which arose with the participants. In spite of everything achieved, in certain sessions, the relationship between the facilitators and the participants was clearly very one-way and unequal in nature, as opposed to democratic. This was seen in the decisions the facilitators had to make unilaterally on occasions, due mainly to the passiveness in response to (and inability to resolve) the various conflicts that arose. In this regard, and despite the fact that the homeless participants took centre stage throughout the process, the facilitators were still seen as being the "experts."

\section{Teatro de la Inclusión: Creative Narratives as a Form of Resistance and Collective Creation}

In this section, we will present some of our experiences with the homeless members of the amateur theatre group Teatro de la Inclusión. The project began in November 2007 with a workshop on social skills for those living at Seville's Municipal Homeless Shelter. The event was attended by nine homeless individuals (seven men and two women) and one of the authors of this article in their role as facilitator (Kaner, 2007). One of the methodological cornerstones of the workshop was the use of techniques taken from theatre pedagogy, which was used as a means through which to help the participants effectively manage their relationships with each other and resolve day-to-day conflicts at the shelter. Initially funded by Senda PDPSH, an NGO which works with homeless individuals, the group subsequently became an independent association and began to meet and perform at various locations throughout the city of Seville, including homeless shelters, parks, squares and state schools (Cordero-Ramos \& Muñoz-Bellerín, 2017). Although the group received help from theatres, universities, and other public and private institutions in the form of financial assistance, equipment, and venues for performances, one of the main features of the initiative was its independence from any organisation.

From 2007 to 2019, sixty-three homeless individuals (fifty-one men and twelve women) participated in Teatro de la Inclusión. The majority were Spanish citizens, although a few were immigrants or refugees from sub-Saharan Africa (three individuals), Eastern Europe (two individuals), and Latin America (three individuals). Of these, nine participated in the project from start to finish (February 2012). Unfortunately, the social and economic instability of homeless individuals, in addition to constant health problems and the fact that they are constantly moving around, meant the members of the group frequently changed. The nine permanent members took on increasingly important roles in the project, becoming facilitators and guiding other participants. One of the group's main aims as part of the participatory process was to maximise each other's creative capacity, as seen by the fact that they took on several, simultaneous roles, such as producer, facilitator, and actor. The project was fundamentally a forum for creating and producing theatrical productions, as well as for expression, reflection, training and social action. In response to the anomie, passiveness, pessimism and hopelessness often seen amongst homeless individuals (Patterson \& Holden, 2012; Vance, 1995), the activities organised with the group initially focused on simple body and acting techniques (Grotowski, 1969), until they became capable of creating theatrical productions based on a model of collective creation, underpinned by an artistic and educational focus.

The dynamic we followed may broadly be divided into the following stages: a workshop to get to know one another; artistic training and preparation; deciding together upon the issues, themes and subthemes to be dealt with; creating micro-stories based on personal experience; theoretical research involving critical analysis in various areas, such as socio-political creation, theatre, and the social sciences; artistic exploration through improvisation; staging and performance. In our case, collective theatre creation involved a process of reflection, communication, and production based on the creative capacities of the participants. During this process, the facilitators guided the debate and made sure everyone had the chance to speak, with the aim of deciding together upon the main topics to be explored, issues relating to aesthetics, and the acting technique(s) to be used. They also recorded what was discussed in the group debates and presented this to the participants to help them in the creative process. By experimenting with various practical acting techniques, they were able to create plays which dealt with their concerns and difficulties, as well as put forward possible solutions. Amongst those most used were image theatre (Boal, 1979), the "magic if" (Stanislavsky, 2016), and improvisation (Johnstone, 1981). Image theatre is based on the conflicts of everyday life and involves constructing three types of images. These are a "real image," how things are, an "ideal image," how things could or should be, and a "transitional image," ideas for helping the group move from the real to the ideal. The "magic if" is a technique that involves the actor putting themselves in the character's shoes, i.e., imagining themselves in a set of fictional circumstances and envisaging the consequences of finding themselves in that situation. Finally, improvision consists of the actor creating meaning using their body and involves a series of images and movements that represent their reality, dreams, needs, and desires.

Our work with Teatro de la Inclusión began by ensuring participants trusted each other and getting them familiar with the drama techniques we would be using. Discussion groups (Ibañez, 2003) were created in which the themes for the collective creations were chosen based on narratives (Bruner, 1990) involving the previously silenced personal experiences of the participants. This group work resulted in the gradual emergence of new identities through the appropriation of discourse (Foucault, 2002) as a means of individual and group recognition. With the aim of facilitating 
this appropriation and encouraging the group to create collective narratives, various approaches were used, such as reminiscence, where group members "share and communicate memories with a view to understanding each other or a shared situation" (Bornat, 2001, p. 223). Through theatre, they were able to express and face their "painful past" (I., female, 55 years old), as well as voice "what it feels like to be misunderstood" (M., female, 53 years old). The narratives were underpinned by an autobiographical approach, which allowed the actors to put their capabilities to use (Nussbaum, 2011) in order to creatively express events in their lives that they considered important.

Furthermore, improvisation allowed the participants to redefine their identity through creative techniques such as image theatre and social "gestus" (Brecht, 2019). Using their bodies, they expressed the oppression (Young, 1990) they experienced at the hands of society and its institutions. During the process, E. M. (male, 48 years old) expressed an opinion common amongst participants when he said: "My life has had so many ups and downs, and has been so unstable. I either had it all or nothing, to the point where l've had to sleep rough, exposed to the elements, and in a really bad way." During a performance, this individual took the audience on a journey during which images of happy memories and then painful ones which led to be him being homeless were acted out. F. J. (male, 40 years old) recalled how a lack of opportunities had prevented him from escaping the vicious cycle of exclusion in which he found himself trapped. The title given by this individual to his story was "The Theory of the Hamster Wheel." When sharing his story, he talked about his aimless day-to-day life in Seville: "I feel like a hamster in a cage. I go from one centre to another, but never manage to escape. The way things are set up, you always find yourself back to square one." The hamster wheel was a metaphor for the alienation he felt when visiting the same places day in, day out, as part of a designated route designed specifically for the city's homeless population. These are places designed to cover the most basic of needs, as reflected in the experience of A. (male, 49 years old): "I spend all day thinking about where I'm going to sleep, and when I can't find anywhere, all that's left is the homeless shelter." By being trapped in such a routine, they are often unable to imagine a brighter future. This is reflected in the experience of C. (male, 53 years old): "All I ask is that they stop judging us based on our past. We want opportunities."

For individuals such as F. (female, 34 years old), being a citizen with rights means "having a space which is ours and ours alone, and being able to say no, something which is difficult when you're homeless because people have already labelled you."

Whilst telling these stories, the actors used their bodies to convey their feelings of helplessness within what Castel calls the "zone of exclusion" (Castel, 2017, p. 391), a space from which it is very difficult to escape. J. V. (male, 59 years old), who had been homeless for a number of years, sleeping in homeless shelters and on the street, explained how "poverty is what it always has been. Ever since I became homeless, absolutely nothing has changed." This was a perspective shared by another participant, J. L. (male, 49 years old), who remarked: "You always meet the same people on the shelters. The people, the routine, they never change." These experiences led one member to ask the rest of the group "where are we now in our lives and where do we want to go?" (M. L., female, 39 years old), a question which was met by bodily expressions which clearly reflected their lack of self-esteem, as well as remarks such as that of $L$. (female, 33 years old): "I'm a nobody."

During the creation process, combatant, dissident voices began to emerge, such as that of L. (female, 33 years old), who affirmed: "We have our dignity and shouldn't care about how people see us." Likewise, M. (female, 52 years old) displayed her creative skills by writing the following poem, clearly showing her capacity for agency:

Big, old wooden mirror, ever-present, looking over me, so indiscreet and cruel. Daunting, constantly observing and always watchful. In spite of my best attempts to avoid you, curiosity has on occasions led me to take a look at myself in you. I would hesitantly approach you, overcome with fear and shame. The reflection staring back at me was in theory me, but a voice in my head would say, "that can't be you!" I was unable to recognise my eyes, skin, smile. I was unable to recognise so much sadness, loneliness, weariness. I was unable to recognise so much emptiness. Then, gradually, each time I looked at myself in you, I could see myself beginning to win the battle against your loyal friends: violence, unemployment, discrimination and loneliness. The only thing that kept me going during those dark days was my resistance and absolute refusal to accept my reflection in you. For years, you won battle after battle, but in the end, I won the war. Now I am fearless when I look at life, you, myself.

This homeless woman used the metaphor of the mirror to express her sense of pain and sadness through comparison and distancing. The author delivered the poem in the form of a monologue at various collective creation performances given by Teatro de la Inclusión in theatres across Seville.

\section{Creating New Public Spaces for Homeless Individuals and Society to Interact}

Over the twelve years that the Teatro de la Inclusión theatre group ran, six plays were produced. These were performed in public spaces in Seville, as well as other cities in Andalusia. Places such as squares, parks, community centres, theatre festivals, universities, homeless shelters, and correctional facilities hosted the events, which 
served as social, political, and cultural platforms through which to establish dialogue between the homeless actors and the audience, members of mainstream society in Seville. Some of the productions were also uploaded to the internet, such as through YouTube (Imolini, 2009), Facebook, and a blog created by some of the members of the group where information about the plays was published and the audience was able to provide feedback (artivismosocialteatrodelainclusion.blogspot.com).

In 2007, during the first collective creation, Tristeza de Mundo (What a Sad World), the group began to explore how they could use their bodies to assert themselves on stage. As part of this learning process, one of the actresses (F., female, 29 years old), reached the following conclusion: "My body allows me to express things from my world where words are not enough." Indeed, this is a world with no formal representation within society, a world where "we don't have a voice or a say in anything" (C., male, 53 years old). In this play, rejection and discrimination were manifested in the verbal and non-verbal language of the actors. The three acts focused on the plight of a group of men and women, wandering around alone in search of a place to inhabit physically and emotionally. In one of the scenes (see Figure 1), the characters expressed their despair at being excluded from mainstream society and not having a family. The actors began each performance by reciting the following statement about how theatre represented a political act for them:

As members of the Teatro de la Inclusión theatre group, we wish to exercise our right to participate in society. We also want to exercise the inalienable right of every individual and group to create culture. For us, culture is a tool which allows us to express our identity, an identity that is our own. We want to be able to freely express ourselves, feel like real citizens once again, and be the masters of our own destiny.

In 2009, the group decided to create a second play, El Drama es Nuestro (The Drama is Ours), with the aim of creating a space and time for themselves within a society that forgets they exist. As part of this theatrical production, the members of the group explored the power of verbal and non-verbal language as tools for reclaiming such a space and time. This involved using memories and dreams in order to imagine the way things could be. For example, one participant talked about a world where "the misfortune of homelessness no longer exists, and everyone is afforded dignity" (J., male, 49 years old). The feeling of being forgotten, a central theme in this play, was manifested through the collective memory of the group. This is a memory which would most likely have remained hidden inside each actor if it had not been for their participation in the play, and can be seen in the following dialogue, which takes place between two characters, a clown and a homeless gipsy:

Homeless gipsy: This is the story of my brothers and sisters. They have never had anything, except the chance to tell their story in this play. We are colourful people and love to sing, but we also suffer. We are mothers, fathers, brothers and sisters who society has forgotten.

Clown (stood in the shadow of a lantern): Oh! So many souls without light, so many dreams denied. Oh! So many stories forgotten, of invisible men and women.

The following play, Naturaleza Humana (Human Nature; see Figure 2), was an exploration of the everyday effects of homelessness. For one of the actresses (M., women, 53 years old), this theatrical production was a faithful depiction of the constant anxiety and "anguish caused by living rough, day in, day out." It focused on the lives of the homeless characters and took place at a crossroads leading nowhere. On cold winter nights, when the rest of society was sleeping, they would meet up to share their secrets with one another. Throughout the play, the longing of the characters for things to be different and for there to be more opportunities was clear. Their shame

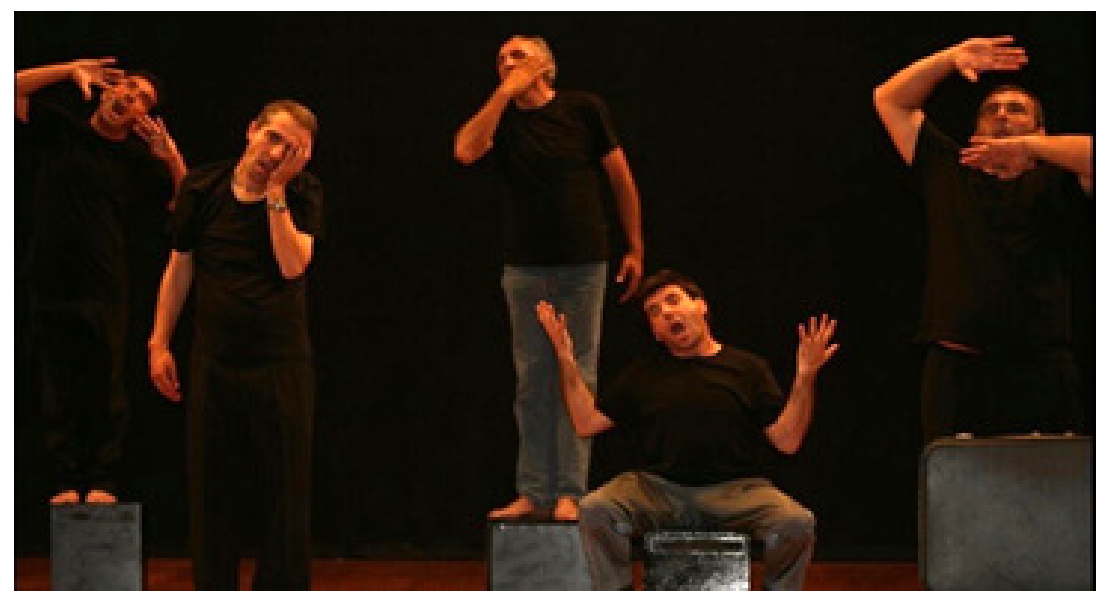

Figure 1. A scene from Tristeza de Mundo in 2008. 


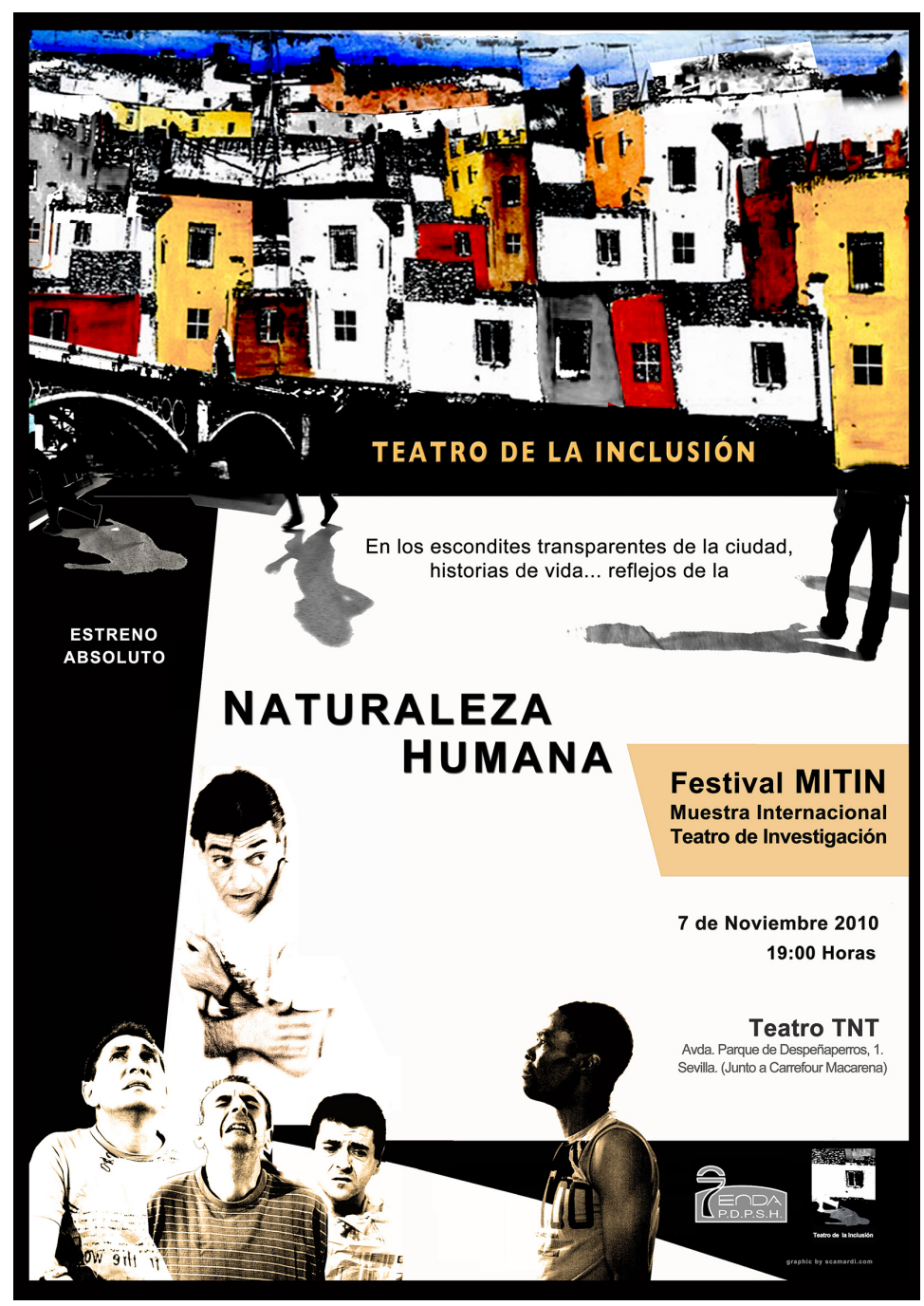

Figure 2. A poster announcing the premiere of Naturaleza Humana at the International Festival of Research Theatre in 2010.

was also painfully visible, as well as their dismay at a society that simply turns a blind eye to their misfortune. During the collective creation process for this play, one of the most heated topics which arose within the group was the assertion of their human rights. For one of the actors (A. J., male, 36 years old), being homeless or jobless was a result of such rights being denied, hence "the important role played by theatre in helping raise awareness on inequality and allowing us to demand we be heard." In one of the scenes, a character, weary and despondent due to intense stigmatisation, and about to fall into the abyss, is helped by another character, who says "don't worry, I'm here for you." The entire play was a symbolic act of oppression and liberation, a dynamic caused in the first place by the institutions which "strip us of our dignity" (C., female, 44 years old). Despite this, in the final act, the characters, in search of their space and time within the story, managed to liberate themselves by fighting back. Individuals who were once trapped in the shadows of the institutions which controlled them expelled the despair which had been building up inside them and began to fly. For J. L (male, 41 years old), this was a metaphorical way of saying "look at me, I'm not invisible. I'm also a person with rights."

The next two collective creations focused on the convergence of fiction and reality. Although the group continued to explore their creative capacities through their experiences, now the focus was on reminiscence involving specific parts of their life stories, which were intertwined with stories invented by the actors. The first of these, Se Comparte Mundo (Shared Lives; see Figure 3), premiered in January 2012 at an alternative cultural centre run by an association. The second one, La Espera (The Wait; see Figure 4), premiered at a public theatre in November 2013. In both productions, drama became a way of expressing a collective memory of a group of individuals living on the fringes of society both literally and figuratively, whose needs and rights are not generally included in political debate. For one of the participants (E., female, 33 years old), these plays represented "a space where we play in freedom, dream of other worlds, and shine a light on the experiences of so 


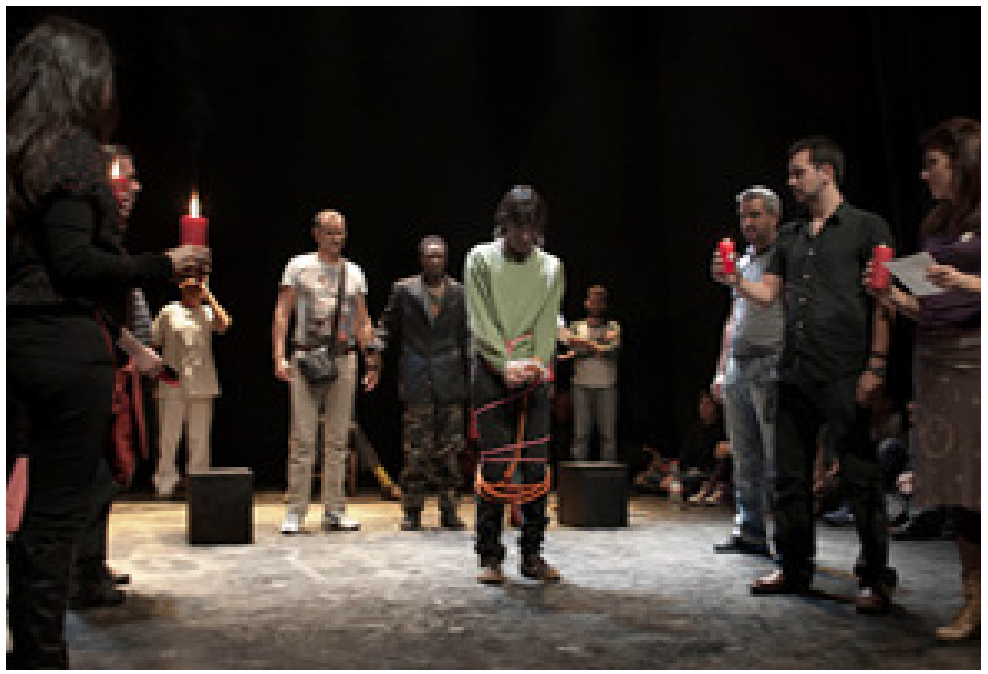

Figure 3. A scene from Se Comparte Mundo in 2012.

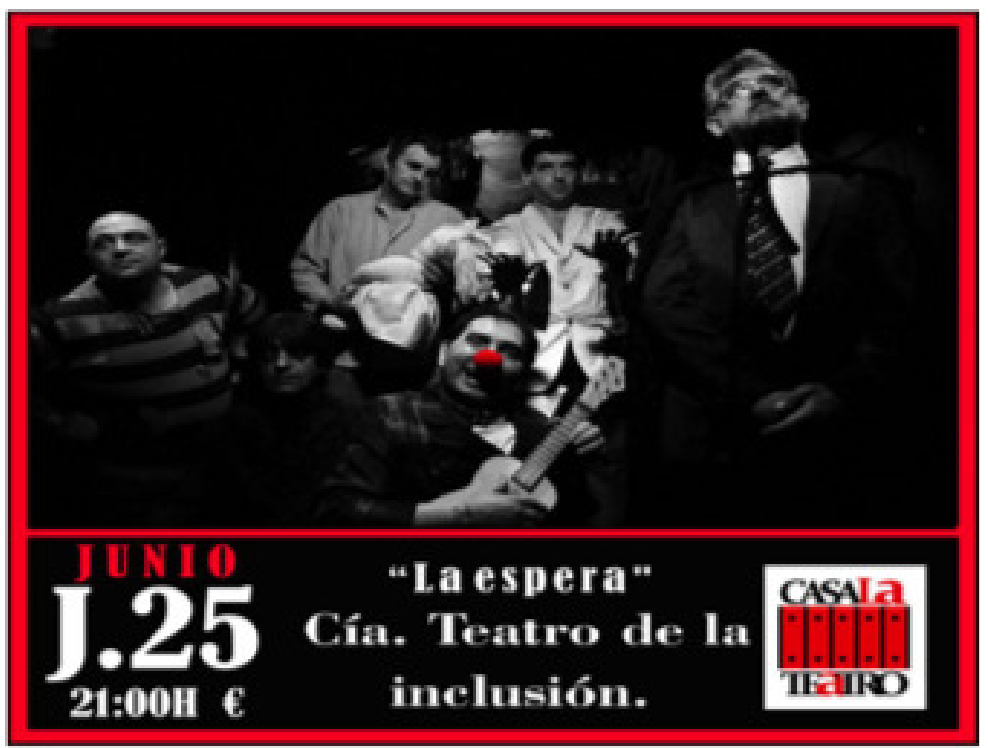

Figure 4. A poster announcing the premiere of La Espera at a theatre in Seville.

many individuals who are not represented by any parliament or government body."

The last collective creation by Teatro de la Inclusión was Breves Relatos de Vergüenza y Olvido (Short Stories of Shame and Neglect; see Figure 5), which was performed at theatres from the end of 2016 until February 2019. In the words of F. (male, 39 years old):

The play tells the stories of anonymous homeless individuals in Seville. In each act, the audience sees how we are misunderstood, suffer, experience violence and see our human rights violated, as well as how we are able to reclaim our dignity and fight back.

For this production, the actors went in search of other homeless individuals to hear their stories, which were told throughout the play. In one scene, channelling the words of one of these homeless individuals, a character exclaimed: "There's an urban legend which says that everyone has the right to a job and a roof over their head. But that's all it is, an urban legend." Once again, the issue of rights was raised, but on this occasion to directly criticise social policies which, through charity and welfare, oppress those they are designed to help, individuals who in practice do not have the same opportunities to create a decent life for themselves as those living within mainstream society. In the face of this neglect from successive governments, the characters displayed their resistance by dancing with members of the audience. Ultimately, this play took the audience on a journey which began with the organised chaos created by institutions which had failed to create a fair society and ended with an act of liberation involving an interaction where the homeless actors were on an equal footing with mainstream society.

As part of all the performances, debates were held between the actors and audience (Figure 6) on the themes highlighted during the plays, as well as aspects 

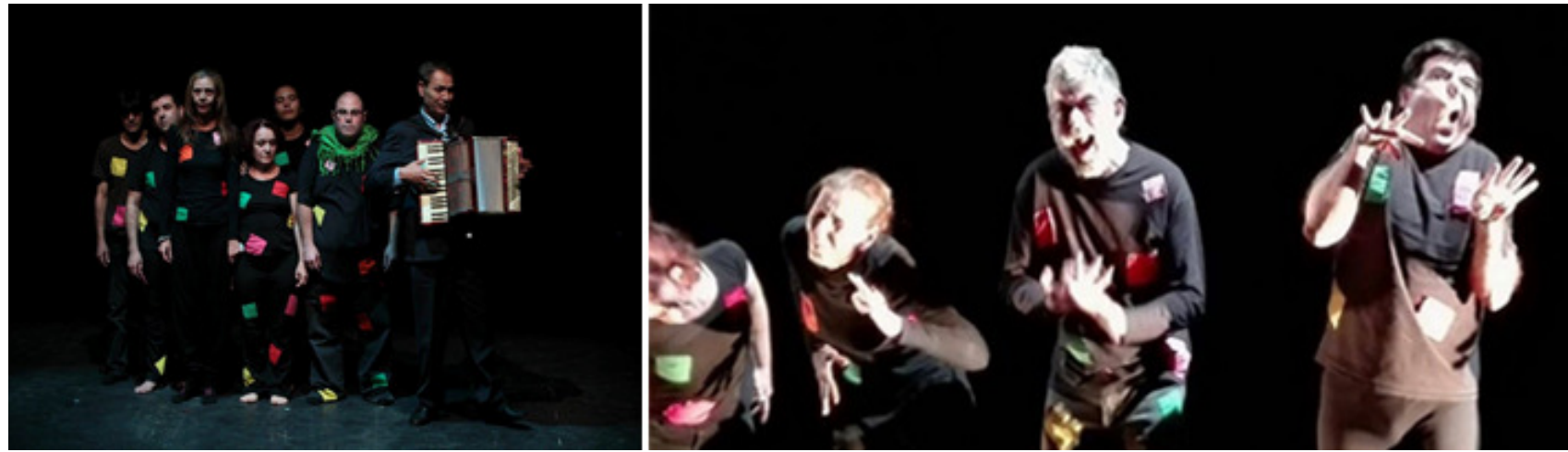

Figure 5. Two scenes from Breves Relatos de Vergüenza y Olvido.

relating to aesthetics, methodology, production, etc. By way of these spaces for dialogue and critical discussion, as well as the plays themselves, the audience was able to learn more about the reality of homeless individuals. For a short space of time, art enabled a dynamic based on participatory democracy using two techniques. On the one hand, through creativity, a group of individuals excluded from mainstream society was able to create something collectively, and thus find their voice and take action (Ricœur, 2005), and on the other hand, through dialogical consensus (Habermas, 2012), different groups within society were able to meet and hear each other's perspectives on homelessness. A particularly salient example of this journey of discovery occurred following a performance of Naturaleza Humana, when a member of the audience noted: "There are lots of people who should watch your play because they have no idea what people like you go through." A similar sentiment was expressed following another play, when a member of the audience remarked: "Nobody deserves to live in such inhumane conditions, without the chance to better their life, something which is so important." Furthermore, during a discussion at the end of a performance of Breves
Relatos de Vergüenza y Olvido, a homeless member of the audience reached the following conclusion: "Now I realise just how important it is that we have a voice with which to fight back. We must start by getting back our life and dignity."

Examples such as these clearly show how collective theatre creations can allow those living on the fringes of the social and political spheres to assert their rights. Teatro de la Inclusión may serve as a model for collective creation and artivism with homeless individuals, a means of denouncing the exclusion suffered by this group within society, and fostering social inclusion by allowing them to appropriate cultural spaces where they are able to become political agents.

In February 2019, the University of Granada organised a seminar on Teatro de la Inclusión. The event ended with the final performance of the group and marked the end of the initiative, which had run for twelve years. The decision to end the project had been taken the previous year for two main reasons. Firstly, the socioeconomic crisis the majority of the participants were living through, meaning certain members were not able to attend the sessions as normal, something which led

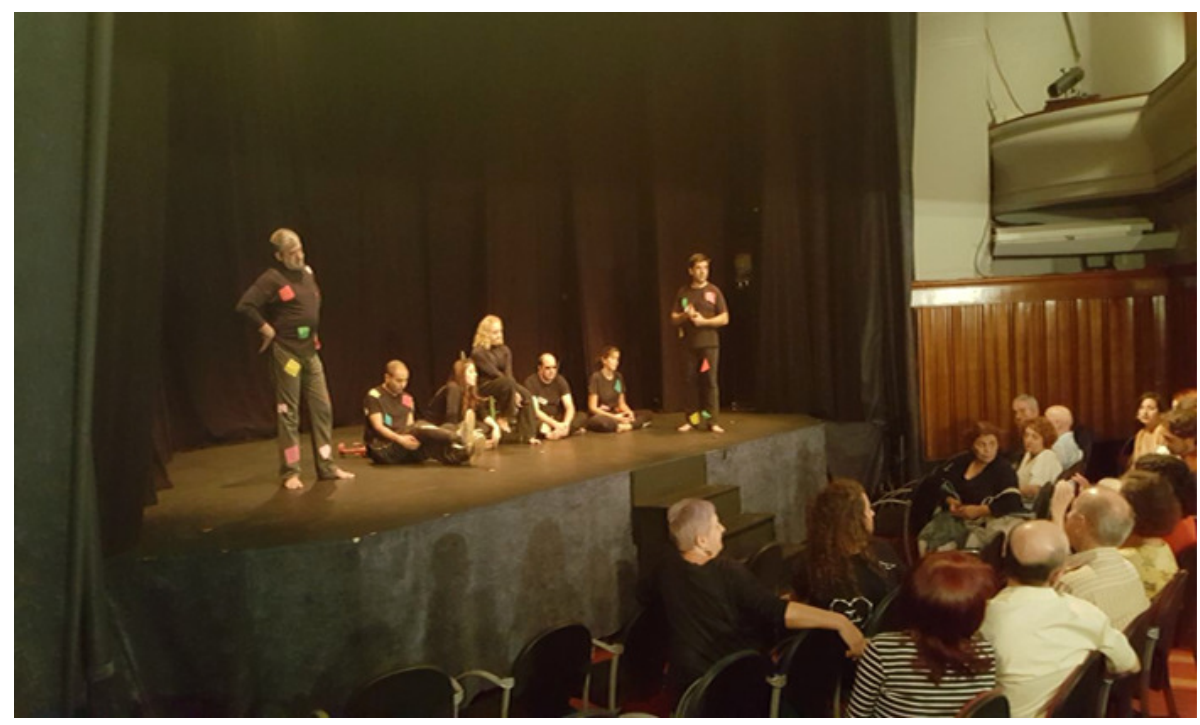

Figure 6. A debate between the actors and audience following a performance by Teatro de la Inclusión. 
to significant issues with group cohesiveness. Secondly, after such a long period involving an intense creative process, members had become tired and, at times, uninterested in the initiative. However, the group does occasionally meet thanks to two participants (a man and a woman), who, from time to time and at certain cultural events, put on adaptations of the six plays created by the group. Thanks to their participation in Teatro de la Inclusión and the subsequent organisation of said events, these two individuals have acquired leadership skills and, as amateur actors, continue to fully participate in Seville's cultural life. Perhaps this will lead to the project being relaunched in the future. Moreover, each year, a considerable number of the participants meet to talk about their time in this cultural, participatory action project as artists and facilitators. At these reunions, the possible return of Teatro de la Inclusión has been talked about on several occasions.

\section{Conclusion}

The work carried out over the twelve years during which Teatro de la Inclusión ran shows how art, and specifically theatre, can be used as an effective tool for giving those living on the fringes of society a voice, as well as tools with which to improve their lives.

Throughout the creative process, the participants were able to take centre stage and tell their story. They were able to make their concerns, frustrations and plight known to the audience, as well as share it with individuals experiencing similar situations. As one of the founders of Teatro de la Inclusión stated, "theatre gives us a voice and allows us to tell things which often go untold" (M., male, 53 years old). This allowed them to assert their individual and group (shared) identity and experiences, as well as reconstruct their identity as fully fledged citizens with a voice. The process prior to the performances also them gave a chance to work as part of a group, where respect, dignity, and understanding dominated, a far cry from the world in which the participants were immersed in their day-to-day lives, this being a learning experience in itself. Furthermore, by appropriating public spaces in the city for the performances, they were able to reclaim the city as theirs. Seville was no longer a city where they felt like outsiders.

The debates held between the actors and the audience opened up a space for meaningful dialogue. These conversations were a chance for both parties to learn from each other, and particularly helped members of the audience learn about the plight of homeless individuals in their city. They also put the participants on an equal footing with mainstream society. This further helped them move from a position of exclusion to one of inclusion. A form of participatory democracy, they were a chance to discuss, analyse and put forward ideas for creating a city (and world) that works for everyone.

Teatro de la Inclusión revealed just how effective art as a technique for creative intervention, and the- atre as a public forum for combatting exclusion, can be in terms of transforming and empowering individuals. Throughout the performances, the silence resulting from being excluded from mainstream society disappeared as bodily expressions, words, images and actions took their place. Thanks to the commitment of the participants and the social and artistic expertise of the facilitators, the project made a real impact. As such, of the sixty-three individuals to participate in Teatro de la Inclusión, eleven (seven men and four women) have been able to get off the streets and find employment. We hope stories like this will serve as motivation for others to organise similar initiatives and help make the world a more inclusive and just place for everyone.

\section{Acknowledgments}

The authors would like to thank all the women and men who participated in Teatro de la Inclusión. They showed just how powerful art can be in terms of creating spaces based on participatory democracy.

\section{Conflict of Interests}

The authors declare no conflict of interests.

\section{References}

Barba, E., \& Savarese, N. (2019). The five continents of theatre: Facts and legends about the material culture of the actor. Koninklijke Brill NV.

Boal, A. (1979). Theatre of the oppressed. Pluto Press.

Bornat, J. (2001). Reminiscence and oral history: Parallel universes or shared endeavour? Ageing \& Society, 21(2), 219-241.

Brecht, B. (2004). Escritos sobre el teatro [Writings on the theatre]. Alba Editorial.

Brecht, B. (2019). Brecht on theatre. Bloomsbury Academic.

Bruner, J. (1990). Acts of meaning. Harvard University Press.

Cardona Garzón, M. (2009). El método de creación colectiva en la propuesta didáctica del maestro Enrique Buenaventura: Anotaciones históricas sobre su desarrollo [The method of collective creation in the educational approach of Enrique Buenaventura: Historical remarks on its development]. Revista Historia de la Educación Colombiana, 12(12), 105-122.

Castel, R. (2017). From manual workers to wage laborers: Transformation of the social question. Routledge.

Castoriadis, C. (1987). The imaginary institution of society. MIT Press.

Cordero-Ramos, N., \& Muñoz-Bellerín, M. (2017). Social work and applied theatre: Creative experiences with a group of homeless people in the city of Seville. European Journal of Social Work, 22(3), 485-498.

Crehan, K. A. F. (2002). Gramsci, culture and anthropology. University of California Press. 
de Sousa Santos, B., \& Sena Martins, B. (2021). The pluriverse of human rights: The diversity of struggles for dignity. Routledge.

Duncombe, S. (2016). Does it work? The æffect of activist art. Social Research: An International Quarterly, 83(1), 115-134.

Foucault, M. (2002). The archaeology of knowledge. Routledge.

Gallardo, H. (2006). Derechos humanos como movimiento social [Human rights as a social movement]. Ediciones desde abajo.

García Pinzón, S. (2002). Teoría y práctica del teatro [Theory and practice of theatre] (Vol. 2). Teatro La Candelaria.

Goffman, E. (1990). Stigma: Notes on the management of spoiled identity. Penguin.

Grotowski, J. (1969). Towards a poor theatre. Methuen.

Habermas, J. (2012). The theory of communicative action. Lifeworld and system: A critique of functionalist reason (Vol. 2). Beacon Press.

Herrera Flores, J. (2005). El proceso cultural: Materiales para la creatividad humana [The cultural process: A tool for human creativity]. Aconcagua Libros.

Herrera Flores, J. (2008). La reinvención de los derechos humanos [The reinvention of human rights]. Librería Atrapasueños.

Holdsworth, N. (2017). Joan Littlewood. Routledge.

Ibañez, J. (2003). Más alla de la sociología: El grupo de discusión : Teoría y crítica [Beyond sociology: Discussion groups: Theory and critique] (5th ed.). Siglo XXI Editores.
Ignatieff, M. (2017). The ordinary virtues: Moral order in a divided world. Harvard University Press.

Imolini. (2009, October 3). Teatro de la inclusión [Video]. https://www.youtube.com/watch?v=VOn-jHQ3XBO

Johnstone, K. (1981). Impro: Improvisation and the theatre. Eyre Methuen.

Kaner, S. (2007). Facilitator's guide to participatory decision-making (2nd ed.). Jossey-Bass.

Muñoz-Bellerín, M., \& Cordero-Ramos, N. (2020). The role of applied theatre in social work: Creative interventions with homeless individuals. The British Journal of Social Work, 50(5), 1611-1629.

Nussbaum, M. C. (2011). Creating capabilities: The human development approach. Belknap Press of Harvard University Press.

Patterson, A. A., \& Holden, R. R. (2012). Psychache and suicide ideation among men who are homeless: A test of Shneidman's model. Suicide and LifeThreatening Behavior, 42(2), 147-156.

Ricœur, P. (2005). The course of recognition. Harvard University Press.

Sikkink, K. (2017). Evidence for hope: Making human rights work in the 21st century. Princeton University Press.

Stanislavsky, K. (2016). An actor's work. Routledge.

Vance, D. (1995). A portrait of older homeless men: Identifying hopelessness and adaptation. Journal of Social Distress and the Homeless, 4(1), 57-71.

Young, I. M. (1990). Justice and the politics of difference. Princeton University Press.

\section{About the Authors}

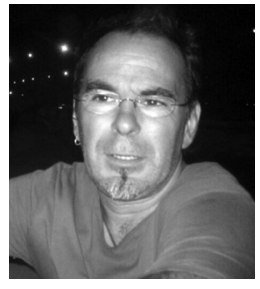

Manuel Muñoz-Bellerín (PhD social sciences) is a lecturer at Pablo de Olavide University, Seville (Spain), where he teaches social work at the undergraduate degree level and social invention at the master's degree level. He has published widely on collective theatre creation as a method of social intervention and applied theatre in the social sciences, and regularly organises and participates in events on the subject in Spain and Latin America. He also runs and acts as a facilitator on socio-artistic projects based on performing arts and social transformation aimed at various groups and professionals.

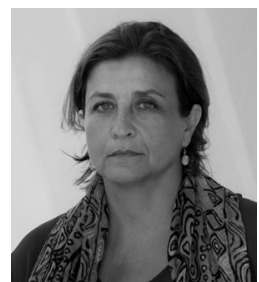

Nuria Cordero-Ramos (PhD human rights and development, MA anthropology, and BA social work) is a lecturer in the Department of Social Work and Social Services at Pablo de Olavide University, Seville (Spain). She is a member of GISAP (Group for Social and Participatory Action) and LIESS (the Ibero-American Laboratory for the Social and Historical Study of Sexuality). Her work is largely based on applied research, which she undertakes using creative tools. She is the author of numerous articles and chapters in books on the use of such tools in the social sciences. 